\title{
PENGAYAAN NUTRISI (FORTIFIKASI) PADA OLAHAN SINGKONG BERBASIS PARTISIPATORIS
}

\author{
Dwi Susilowati ${ }^{1}$, Siti Asmaniah Mardiyani ${ }^{2}$ \\ ${ }^{1}$ Program Studi Agribisnis, Fakultas Pertanian, Universitas Islam Malang \\ email: dwis@@unisma.ac.id \\ ${ }^{2}$ Program studi Agroteknologi, Fakultas Pertanian, Universitas Islam Malang \\ email: asmaniyah@unisma.ac.id
}

\begin{abstract}
Southern Malang region is the center of cassava producers in Malang Raya area. In Tempursari Village, Donomulyo District, Malang Regency, processing of cassava has not been done optimally. There has been limited effort to enrich the processed cassava with additional high nutrition. Cassava peel waste also has not been utilized optimally by the residents. Therefore, counseling and advocacy activities of nutrition enrichment technology on cassava processing is essential to be applied. Service activities were done through diffusion activities related to the application of cassava processing technology to Islamic Women Organization based on Nahdhatul Ulama (Muslimat-NU) board in Tempursari Village, Donomulyo District, Malang in a participatory way. The technology applied was a simple nutrient fortification technology, with green beancrushed cassava steam, cassava brownies, protein-rice cassava rice, protein-rich cassava flour, natural healthy cassava peel sauce. The results of this activity were: a. There was an increasing pattern of public understanding of the importance of cassava enrichment nutrition among the participants. It encouraged them to do various innovations in creating high economic value of cassava processed food. $b$. There was an increasing pattern of skill society in adopting cassava processing fortification technology. It showed that feasibility of cassava as the resource of nutritious staple food increased. Therefore the community will become more productive and innovative, and the technology disseminated in this activity could be further developed and popularized.
\end{abstract}

Keywords: fortification; cassava processed; participatory

\begin{abstract}
ABSTRAK
Wilayah malang selatan merupakan sentra penghasil singkung di wilayah Malang Raya. Di Desa Tempursari Kecamatan Donomulyo Kabupaten Malang pengolahan olahan singkong belum dilakukan secara optimal. Sampai saat ini belum ada upaya untuk memperkaya olahan singkong dengan tambahan nutrisi tinggi. Limbah kulit singkong juga belum dimanfaatkan oleh warga. Oleh karena itu kegiatan penyuluhan dan advokasi teknologi pengayaan nutrisi pada pengolahan singkong penting untuk diterapkan. Metode pelaksanaan kegiatan pengabdian fortifikasi dilakukan melalui kegiatan penyuluhan dan pendampingan terkait dengan penerapan teknologi pengolahan singkong kepada para pengurus Muslimat di Desa Tempursari Kecamatan Donomulyo, Malang secara partisipatoris. Teknologi yang diterapkan adalah teknologi fortifikasi nutrisi sederhana, dengan produk gethuk singkong kacang hijau, brownies singkong, nasi timbel singkong, tim singkong, tepung singkong kaya protein, saos kulit
\end{abstract}


singkong sehat alami. Hasil kegiatan ini adalah: a. Pemahaman masyarakat tentang pentingnya teknologi pengayaan nutrisi olahan singkong meningkat dan mereka terdorong untuk melakukan berbagai inovasi yang dapat meningkatkan nilai tambah olahan singkong, b.Ketrampilan masyarakat dalam mengadopsi teknologi pengayaan nutrisi (fortifikasi) olahan singkong yang memiliki kelayakan sebagai sumber pangan pokok bergizi tinggi meningkat dan diharapkan masyarakat akan menjadi lebih produktif dan berani berivovasi. Oleh karena itu teknologi fortifikasi singkong bisa dikembangkan lebih lanjut dan dimasyarakatkan pada semua warga sehingga nantinya bisa menjadi budaya yang baik dan dapat menjadi sumber pendapatan tambahan bagi rumah tangga di desa Tempursari.

Kata Kunci: fortifikasi; olahan singkong; partisipatoris

\section{PENDAHULUAN}

Kabupaten Malang secara umum dikelompokkan menjadi dua wilayah, yaitu Malang bagian utara dan Malang bagian selatan. Daerah Malang Utara meliputi seluruh area yang air hujannya mengalir ke Sungai Brantas, sedangkan daerah Malang Selatan mengalirkan air hujannya ke sungai-sungai yang bermuara ke laut selatan. Daerah Malang Selatan memiliki banyak faktor keterbatasan, dibandingkan dengan Malang bagian utara, baik dari segi sumberdaya alam maupun sumberdaya manusia. Faktor keterbatasan sumberdaya alam tersebut antara lain sebagian besar lahannya merupakan jenis tanah yang peka erosi, mempunyai kelerengan yang tinggi dengan solum yang dangkal dan memiliki lahan kritis mencapai 21.292 ha atau $18.02 \%$ dari seluruh wilayah Malang Selatan. Hal tersebut diperparah dengan rendahnya curah hujan, sehingga berpengaruh terhadap produktifitas lahan usahatani dan tingkat kesejahteraan penduduknya (Statistik, B.P.,2017).

Wilayah Malang Selatan sangat potensial untuk dikembangkan sebagai pusat budidaya pertanian komoditas pertanian yang tidak memerlukan penyediaan air yang banyak seperti singkong. Singkong atau ubi kayu (Manihot esculenta Crantz) merupakan bahan pangan potensial masa depan dalam tatanan pengembangan agribisnis dan agroindustri. Singkong merupakan salah satu komoditi yang banyak dijumpai di daerah tertinggal seperti di daerah Malang Selatan. Upaya pengolahan lanjut singkong diperlukan untuk menunjang program diversifikasi pangan yang akan berdampak positif terhadap peningkatan nilai tambah komoditas Ginting, E. (2008). Pemanfaatan singkong melalui pemanfaatan secara optimal akan mendorong peningkatan kesejahteraan masyarakat. Pengolahan singkong secara terpadu pada skala rumah tangga merupakan salah satu upaya untuk mengoptimalkan setiap tahapan proses pengolahan singkong dan pemanfaatan hasil samping yang timbul dari industri tersebut, sebagai upaya untuk meningkatkan nilai tambah singkong(Soekarti, M., \& Kartono, D. ,2004).

Berdasarkan survey awal diketahui bahwa penanganan singkong di lokasi sasaran pengabdian yaitu Desa Tempursari Kecamatan Donomulyo Kabupaten Malang belum optimal sehingga hasil yang dicapai tidak optimal. Sampai saat ini belum ada upaya untuk memperkaya olahan singkong dengan 
tambahan nutrisi tinggi. Hasil samping yang berupa kulit singkong juga hanya ditumpuk dalam bentuk onggokan. Dengan introduksi teknologi yang disesuaikan dengan kondisi pedesaan yang serba terbatas modal dan sumberdaya manusianya diharapkan ada peningkatan kualitas produk olahan serta tambahan pendapatan dari pengolahann singkong secara terpadu. Oleh karena itu Penerapan Teknologi Pengayaan Nutrisi (fortifikasi) pada Olahan Singkong Sebagai Sumber Pangan Pokok Alternatif penting dilakukan guna mendukung ketahanan pangan masyarakat desa tempursari. Tujuan dari kegiatan ini antara lain adalah: a. Masyarakat memiliki pemahaman tentang arti penting teknologi pengayaan nutrisi pada olahan singkong dan terdorong untuk melakukan berbagai inovasi yang dapat meningkatkan nilai tambah olahan singkong, b. Masyarakat meningkat ketrampilannya dalam mengadopsi teknologi pengayaan nutrisi (fortifikasi) olahan singkong yang memiliki kelayakan untuk dipergunakan sebagai sumber pangan pokok bergizi tinggi sehingga masyarakat menjadi produktif.

\section{METODE PELAKSANAAN}

Program Pengabdian Kepada Masyarakat dilakukan didaerah Malang Selatan yaitu Desa Tempursari Kecamatan Donomulyo yang berjarak $50 \mathrm{Km}$ dari Kota Malang, Pengabdian berkaitan dengan penerapan IPTEKS pengayaan nutrisi (fortifikasi) pada olahan pangan berbasis singkong dalam rangka menanggulangi ancaman kekurangan gizi pasa wilayah rawan pangan. Responden yang diambil sebanyak 37 orang yaitu para pengurus Muslimat NU Desa Tempursari. Metode penerapan teknologi yang dilakukan melalui pendekatan praktek (Suharsani Arikunto, 2002) dengan tahapan-tahapan berikut:

1. Tahap Pengenalan

Pada tahap ini mulai dilakukan perkenalan pada khalayak sasaran terutama lembaga-lembaga yang menjadi sasaran penerapan Iptek, bagaimana minat dari khalayak sasaran kita lihat dan akhirnya kita tentukan jadwal dari pelaksanaan kegiatan.

2. Tahap Pelaksanaan

Pada tahap ini adalah tahap melaksanakan penyuluhan/pemasyarakatan teknologi pengolahan singkong sesuai dengan penjadwalan yang telah dibuat bersama-sama antara tim dengan khalayah sasaran. Penyuluhan merupakan metode yang tepat dalam rangka meningkatkan wawasan daan pengetahuan masyarakat (Soedarmanto,1993). Teknologi pengolahan singkong yang akan dimasyarakatkan adalah teknologi fortifikasi nutrisi sederhana (Susilawati dan Samru u.N. 2008) dengan produk sebagai berikut:

a. Gethuk singkong kacang hijau : adalah olahan gethuk yang diperkaya dengan tepung kacang hijau sebagai sumber protein, vitamin B dan mineral. Untuk menguatkan rasa dan memperkaya kandungan antioksidan ditambahkan bubuk kayu manis dan jahe. 
b. Brownies Singkong : adalah produk olahan singkong yang diperkaya dengan penggunaan susu, margarin dan telur sebagai sumber protein.

c. Nasi timbel singkong : adalah produk olahan singkong sebagai pengganti nasi yang diperkaya dengan sumber vitamin dan mineral (bumbu dan rempah), sumber protein dan kalsium (ikan teri) serta sumber antioksidan.

d. Tepung singkong kaya protein : adalah pembuatan tepung singkong dengan tambahan ekstrak tepung kedele dan tepung kacang hijau. Produk tepung singkong kaya protein adalah produk olahan setengah jadi yang dapat diolah lebih lanjut menjadi produk yang siap dikonsumsi (Perdana, R. Y., 2006); Indrie Ambarsari, S., \& Choliq, A., 2009).

e. Saos kulit singkong dengan perasa dan pewarna rosella, adalah olahan kulit singkong dengan tambahan ekstrak rosella, bumbu dan rempah untuk menghasilkan saos alami bergizi tinggi.

3. Tahap Evaluasi

Tahap evaluasi kegiatan dilakukan dengan cara wawancara dan penyebaran quesioner. Data yang telah diperoleh akan dianalisis untuk mengetahui apakah ada perbedaan mengenai pemahaman dan ketrampilan masyarakat sebelum dan sesudah adanya Program Pengabdian pada Masyarakat. Analisis data secara statistik menggunakan Paired sample t tes yang mana menggunakan hipotesis dan pengambilan keputusan sebagai berikut:

Hipotesis:

$\mathrm{H}_{0}: \mathrm{D}=0$, berarti rata-rata data sebelum dan sesudah pengabdian adalah sama/tidak berbeda nyata).

$\mathrm{H}_{\mathrm{i}}: \quad \mathrm{D} \neq 0$, berarti rata-rata data sebelum dan sesudah pengabdian adalah tidak sama/berbeda nyata).

Pengambilan keputusan:

a. Jika probabilitas $>0,05$ maka $\mathrm{H}_{0}$ diterima.

b. Jika probabilitas $<0,05$ maka $\mathrm{H}_{0}$ ditolak. (Singgih Santoso, 2006).

\section{HASIL DAN PEMBAHASAN}

A. HASIL

\section{Karakteristik Responden}

Responden dalam kajian ini adalah peserta kegiatan yakni para ibu pengurus Muslimat Desa Tempursari, Kecamatan Donomulyo, Kabupaten Malang. Karakteristik responden yang diidentifikasi dalam kegiatan ini meliputi pendidikan, usia dan jenis pekerjaan responden. Data pendidikan menunjukkan bahwa sebagian besar peserta yang merupakan pengurus inti Muslimat di Desa Tempursari berpendidikan Sekolah Dasar $(40.5 \%)$ dan hanya 1 orang $(2.7 \%)$ saja yang berpendidikan sarjana. Dengan latar belakang pendidikan yang tergolong masih rendah maka pendampingan-pendampingan tentang 
peningkatan gizi keluarga dengan mengoptimalkan sumberdaya yang ada merupakan hal yang sangat penting dalam rangka meningkatkan kualitas kehidupan keluarga responden. Sebagaian besar responden berumur lebih dari 41 tahun $(54.1 \%)$, dan terdapat $43.2 \%$ yang berumur antara 26 sampai 40 tahun. Dari data tersebut dapat dikatakan bahwa responden rata-rata berada pada usia produktif.
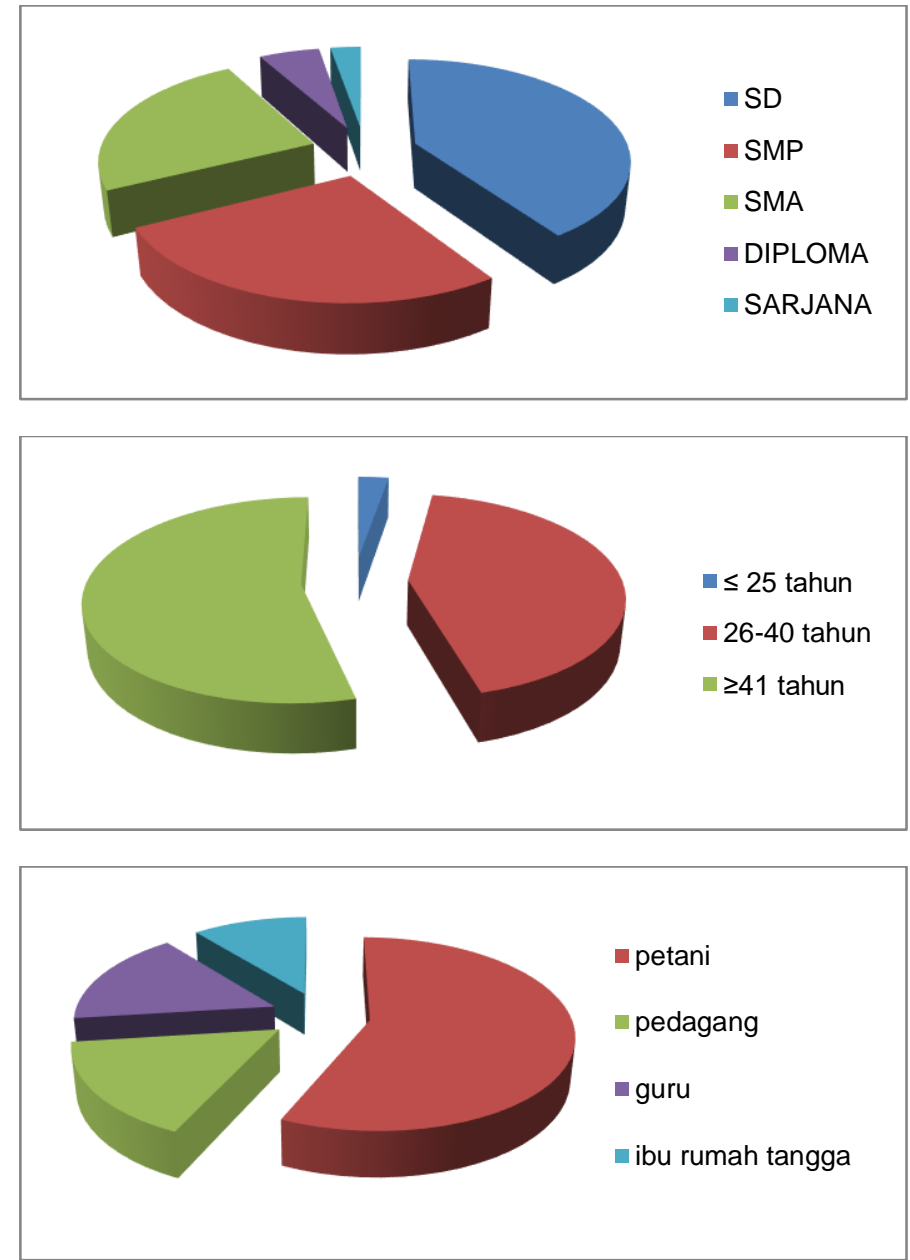

Gambar 1. Karakteristik Responden Sasaran (a. Pendidikan responden; b. usia responden; c. pekerjaan responden)

Sementara itu Gambar 1 (c) menunjukkan bahwa 56.8\% responden bekerja sebagai petani, $16.2 \%$ bekerja sebagai pedagang, $16.2 \%$ sebagai guru dan hanya $10.8 \%$ sebagai ibu rumah tangga biasa. Pekerjaan responden ini berperan pada lancar atau tidaknya pendampingan karena berkaitan dengan waktu yang disediakan untuk mengikuti kegiatan pendampingan fortifikasi. Karena pekerjaan 
responden sebagian besar adalah petani maka waktu yang diluangkan untuk kegiatan fortifikasi selalu dilakukan pada siang hari setelah pulang dari ladang, menyesuaikan waktu luang.

\section{Persepsi Responden}

\section{$>$ Persepsi 1}

Persepsi 1 merupakan pendapat responden berkaitan dengan olahan ubi kayu digunakan sebagai alternatif pengganti nasi. Data diambil sebelum penyampaian materi penyuluhan dan sesudahnya. Hasil dari wawancara adalah sebagai berikut:

Tabel 1.

Data pernyataan responden mengenai olahan ubi kayu dipakai sebagai alternatif pengganti nasi

\begin{tabular}{ccccc}
\hline \multirow{2}{*}{ Pernyataan } & \multicolumn{2}{c}{ Sebelum } & \multicolumn{2}{c}{ Sesudah } \\
\cline { 2 - 5 } & Frequency & Percent & Frequency & Percent \\
\hline setuju & 13 & 35.1 & 33 & 89.2 \\
tidak setuju & 19 & 51.4 & 3 & 8.1 \\
tidak tahu & 5 & 13.5 & 1 & 2.7 \\
Total & 37 & 100.0 & 37 & 100.0 \\
\hline
\end{tabular}

Sumber: Data Primer

Hasil tabulasi menunjukkan bahwa pernyataan responden yang menyatakan setuju bahwa olahan ubi kayu dapat digunakan sebagai alternatif pengganti nasi sebesar $35,1 \%$ sebelum adanya kegiatan fortifikasi dan $89,1 \%$ sesudah adanya kegiatan fotifikasi.Sedangkan responden yang menyatakan tidak setuju bahwa olahan ubi kayu dapat digunakan sebagai alternatif pengganti nasi sebesar $51,4 \%$ sebelum adanya kegiatan fortifikasi dan $8,1 \%$ sesudah adanya kegiatan fotifikasi.Dan responden yang menyatakan tidak tahu bahwa olahan ubi kayu dapat digunakan sebagai alternatif pengganti nasi sebesar $13,5 \%$ sebelum adanya kegiatan fortifikasi dan $2,7 \%$ sesudah adanya kegiatan fotifikasi.

\section{$>$ Persepsi 2}

Persepsi 2 merupakan pendapat responden berkaitan dengan apakah ubi kayu merupakan makanan yang bergizi tinggi. Data diambil sebelum penyampaian materi penyuluhan dan sesudahnya. Hasil dari wawancara adalah sebagai berikut: 
Tabel 2.

Data pernyataan responden mengenai apakah ubi kayu merupakan makanan yang bergizi tinggi

\begin{tabular}{ccccc}
\hline \multirow{2}{*}{ Pernyataan } & \multicolumn{2}{c}{ Sebelum } & \multicolumn{2}{c}{ Sesudah } \\
\cline { 2 - 5 } & Frequency & Percent & Frequency & Percent \\
\hline setuju & 11 & 30 & 32 & 84 \\
tidak setuju & 21 & 57 & 3 & 11 \\
tidak tahu & 5 & 14 & 2 & 5 \\
Total & 37 & 100.0 & 37 & 100.0 \\
\hline
\end{tabular}

Sumber: Data Primer

Hasil tabulasi menunjukkan bahwa pernyataan responden yang menyatakan setuju bahwa ubi kayu merupakan makanan yang bergizi tinggi sebesar $30 \%$ sebelum adanya kegiatan fortifikasi dan $84 \%$ sesudah adanya kegiatan fotifikasi.Sedangkan responden yang menyatakan tidak setuju bahwa ubi kayu merupakan makanan yang bergizi tinggi sebesar $57 \%$ sebelum adanya kegiatan fortifikasi dan $11 \%$ sesudah adanya kegiatan fotifikasi.Dan responden yang menyatakan tidak tahu bahwa ubi kayu merupakan makanan yang bergizi tinggi sebesar $14 \%$ sebelum adanya kegiatan fortifikasi dan $5 \%$ sesudah adanya kegiatan fotifikasi.

\section{Persepsi 3}

Persepsi 3 merupakan pernyataan responden berkaitan dengan apakah bisa mengolah ubi kayu untuk dijadikan makanan yang bergizi tinggi. Data diambil sebelum penyampaian materi penyuluhan dan sesudahnya. Hasil dari wawancara adalah sebagai berikut:

Tabel 3.

Data pernyataan responden mengenai apakah bisa mengolah ubi kayu untuk dijadikan makanan yang bergizi tinggi.

\begin{tabular}{ccccc}
\hline \multirow{2}{*}{ Pernyataan } & \multicolumn{2}{c}{ Sebelum } & \multicolumn{2}{c}{ Sesudah } \\
\cline { 2 - 5 } & Frequency & Percent & Frequency & Percent \\
\hline bisa & 10 & 27 & 35 & 95 \\
tidak bisa & 27 & 73 & 2 & 5 \\
Total & 37 & 100 & 37 & 100 \\
\hline
\end{tabular}

Hasil tabulasi menunjukkan bahwa pernyataan responden yang menyatakan bisa mengolah ubi kayu untuk dijadikan makanan yang bergizi tinggi sebesar $27 \%$ sebelum adanya kegiatan fortifikasi dan $95 \%$ sesudah adanya kegiatan fotifikasi.Sedangkan 
responden yang menyatakan tidak bisa mengolah ubi kayu untuk dijadikan makanan yang bergizi tinggi sebesar $73 \%$ sebelum adanya kegiatan fortifikasi dan $5 \%$ sesudah adanya kegiatan fotifikasi.

\section{B. PEMBAHASAN}

Kegiatan fortifikasi yang diterapan pada masyarakat Tempursari kecamatan Donomulyo Malang Selatan dapat dilihat dari perubahanperubahan yang terjadi yaitu terkait dengan perubahan pemahaman dan ketrampilan mengenai fortifikasi yang disampaikan melalui kuesioner yang dibagikan sebelum kegiatan dan sesudah kegiatan. Secara rinci perubahan-perubahan masyarakat disampaikan dalam analisis berikut:

\section{Pemahaman Masyarakat mengenai Fortifikasi Olahan Ubi Kayu}

Hasil analisis statistik paired sample $t$ tes terkait pemahaman masyarakat tentang fortifikasi sebelum pelaksanaan pengabdian berbeda nyata dengan pemahaman masyarakat sesudahnya. Secara umum terjadi peningkatan pemahaman tentang fortifikasi karena penyampaian materi dilakukan dengan menyesuaikan kondisi masyarakat yang sebagian besar berpendidikan Sekolah Dasar. Penyampaian disamping materinya tetapi juga didampingi selain dari dosen juga melibatkan mahasiswa, sehingga bisa lebih intensif. Disamping itu hal tersebut terjadi juga sebagai akibat tingginya antusiasme masyarakat dalam mengikuti penyuluhan dan praktek. Pelaksanaan kegiatan dilakukan pada saat mereka sudah bekerja dari sawah, karena sebagian besar warga NU muslimat sebagai petani. Pemahaman fortifikasi yang dipahami oleh masyarakkat bahwa untuk hidup dengan kualitas yang baik harus didukung oleh makanan yang mempunyai gizi yang seimbang dan kesehatan. Pemahaman tersebut penting artinya agar masyarakat secara mandiri dapat mengatasi permasalahan yang terkait dengan kondisi daerah di Malang selatan yang kering dengan ubi kayu sebagai komoditas utama. Dengan pemahaman tersebut masyarakat akan dapat mengkonsumsi ubi kayu dengan yang diperkaya dengan penambahan komoditi lain sehingga nilai gizinya saling melengkapi. Disamping itu pemahaman tersebut dapat mengatasi resiko kekurangan gizi dalam keluarga.

\section{Ketrampilan Masyarakat dalam Fortifikasi Olahan Ubi Kayu}

Hasil analisis statistik paired sample $t$ tes menunjukkan bahwa ketrampilan masyarakat tentang fortifikasi sebelum pelaksanaan pengabdian berbeda nyata dengan pemahaman masyarakat sesudahnya. Hal ini terlihat dari signifikansi dari uji t yaitu sebesar 0.000 yang mana berarti dibawah 0,05 sehingga $\mathrm{H}_{0}$ ditolak yang pengertiannya bahwa terdapat perbedaan secara nyata antara 
ketrampilan sebelum adanya penyuluhan dan pendampingan fortifikasi dan sesudah adanya penyuluhan dan pendampingan fortifikasi.

Peningkatan ketrampilan tentang fortifikasi olahan ubi kayu terjadi karena materi dikemas dengan sederhana, bahan yang digunakan mudah diperoleh didaerah Tempursari tersebut dan alat-alat yang digunakanpun sederhana. Ketrampilan masyarakat yang bisa ditingkatkan adalah berkaitan dengan ketrampilan penambahan vitamin, mineral dan protein, Vitamin, mineral atau protein dapat diperoleh dari buah,sayur, tempe, tahu, ikan dan lain-lain. Ketrampilan masyarakat berkaitan dengan bagaimana membuat Gethuk singkong kacang hijau, Brownies Singkong, Nasi timbel singkong, Tepung singkong kaya protein dan Saos kulit singkong dengan perasa dan pewarna rosella.

\section{Implikasi dan Temuan}

Implikasi dari pemahaman dan ketrampilan fortifikasi yang meningkat adalah masyarakat dapat meningkatkan gizi dengan memanfaatkan komoditi unggulan daerah yang mana nantinya kedepan dapat disebarluaskan kepada masyarakat yang lain atau lebih jauh lagi dapat digunakan untuk kegiatan yang bernilai ekonomis dan dapat membantu perekonomian rumah tangga.

Temuan dilapang adalah bahwa masyarakat yang aktif sudah banyak yang berusia lebih dari 40 tahun karena generasi muda banyak yang bekerja sebagai TKW di luar negeri.

\section{KESIMPULAN DAN SARAN}

\section{A. KESIMPULAN}

Dari kegiatan fortifikasi yang dilakukan di Desa Tempursari Kecamatan Donomulyo yaitu khususnya pada warga NU muslimat di tingkat ranting diketahui bahwa kegiatan yang dilakukan tersebut dapat menambah wawasan, pengetahuan dan ketrampilan masyarakat dalam pengolahan singkong sebagai alternatif pangan pokok yang memiliki nilai gizi dan nilai ekonomi tinggi.

\section{B. SARAN}

Fortifikasi pada ubi kayu bisa dikembangkan lebih lanjut dan dimasyarakatkan pada semua warga sehingga nantinya bisa menjadi budaya yang baik. 


\section{DAFTAR RUJUKAN}

Statistik, B. P., (2017). Kabupaten Malang Dalam Angka Tahun 2017. Malang

Soekarti, M., \& Kartono, D., (2004). Widykarya Nasional Pangan dan Gizi Di Era otonomi Daerah dan Globalisasi. Jakarta: LIPI.

Ginting, E. (2008). Teknologi penanganan pascapanen dan pengolahan ubikayu menjadi produk antara untuk mendukung agroindustri. Buletin Palawija, (4), 67-83.

Singgih Santoso, 2006. SPSS Statistik Parametrik. Elex Media Komputindo. Jakarta.

Soedarmanto, (1993). Dasar-dasar Penyuluhan Pertanian. Universitas Brawijaya Malang.

Suharsani Arikunto, (2002). Prosedur Penelitian Suatu Pendekatan Praktek. PT. Rineka Cipta. Jakarta.

Susilawati dan Samru u.N. 2008. Fortifikasi zat Besi Pada Permen Karamel Susu Untuk Mengatasi penyakit Difesiensi Zat Besi.

Indrie Ambarsari, S., \& Choliq, A., (2009). Rekomendasi dalam penetapan standar mutu tepung ubi jalar. Ungaran: Balai Pengkajian Teknologi Pertanian (BPTP).

Perdana, R. Y., (2006). Pembuatan Mie Kering Dari Tepung Komposit (Terigu Dan Serbuk Ubi Kayu) yang Difortifikasi Tepung Kacang Tunggak. 